\title{
Association of methyltetrahydrofolate reductase gene mutation, homocysteine level with semen quality of Iraqi infertile males
}

Anwar Madlool Al-janabi ${ }^{*} \mathbb{0}$, Salih Mahdi Al-Khafaji ${ }^{2}$ and Shehab Ahmed Faris ${ }^{3}$

\begin{abstract}
Background: Infertility is very common condition and almost $50 \%$ of cases are due to male factors. Several genetic and environmental factors are responsible for the poor quality and reduced number of sperms in several cases of infertility. The present study was designed to investigate the association between semen parameters, homocysteine, and the risk of C677T polymorphism of MTHFR gene in infertile males of Iraqi population.
\end{abstract}

Methods: This Case-control study has been conducted from February 2019 to July 2021 at a molecular laboratory in the Anatomy and Histology Department/college of Medicine/University of Kufa/Najaf/Iraq. It was composed of 353 infertile male patients. They were divided into five groups: 90 azoospermic, 84 oligospermia, 64 asthenospermic, 50 oligoasthenospermic, and 65 teratospermic with an age range 20-46 years compared with 100 fertile males as control with age range 21-49 years. In order to detect homocysteine levels, we used Hcy ELISA Kit. C677T mutation of MTHFR gene was employed by PCR-RFLP technique.

Results: Our data revealed three genotypes of MTHFR C677T, 167 (47.3\%) subjects had CC genotype, 116 (32.9\%) subjects had CT genotype and 70 (21.1\%) subjects had TT genotype. Furthermore, T allele was associated with higher risk of infertility in all patients groups for any genetic model. In total infertile subjects (codominant model: CT vs. CC, $\mathrm{OR}=2.0,95 \% \mathrm{C} . \mathrm{I}=1.2-3.3, P=0.011$; TT vs. CC, $\mathrm{OR}=4.8,95 \% \mathrm{C} . \mathrm{I}=3.3-8.2, P=0.0003$; dominant model: $\mathrm{CT}+\mathrm{TT}$ vs. $\mathrm{CC}, \mathrm{OR}=2.8,95 \% \mathrm{C} . \mathrm{I}=1.7-4.5, P=0.0001)$. Oligoasthenospermic patients associated with higher risk in CT heterozygous genotype $(\mathrm{OR}=2.8,95 \% \mathrm{C} . \mathrm{I}=1.0-4.9, P=0.03)$ and $\mathrm{TT}$ homozygous of mutant allele $(\mathrm{OR}=6.3,95 \% \mathrm{C} . \mathrm{I}=1.9-9.2$, $P=0.002)$. Homocystein level was elevated in all infertile groups when compared with control group $(P<0.01)$, but the elevation was marked in oligoasthenospermia group. As well as, the level of Serum Hcy exhibited the highest value in TT mutant genotype $(39.7 \mu \mathrm{mol} / \mathrm{ml})$ followed by CT genotype $(28.5 \mu \mathrm{mol} / \mathrm{ml})$ while the lowest level of Hcy recorded in CC genotype $(14.6 \mu \mathrm{mol} / \mathrm{ml})$ for oligoasthenospermia group.

Conclusions: By relating the MTHFR C677T gene mutation with a higher homocystein level, the results showed that Iraqi males with this mutation are more likely to suffer from infertility.

Keywords: MTHFR C677T gene, Mutation, Homocystein, Infertility, PCR-RFLP, Iraq

\footnotetext{
*Correspondence: anwar.aljanabi@uokufa.edu.iq

1 Department of Clinical Chemistry, College of Medicine, University

of Kufa, Najaf, Iraq

Full list of author information is available at the end of the article
}

\begin{abstract}
Background
Infertility is a common health problem, affecting approximately $15-20 \%$ of couples who approaching childbearing age. Almost $50 \%$ of infertility due to male factors [1]. About $12 \%$ of men suffer from male infertility and approximately $15-30 \%$ of male infertility is attributed to genetic abnormalities, which include $\mathrm{Y}$ chromosome
\end{abstract}


microdeletions, chromosomal aberrations, translocation, and single gene mutation. Several factors may contribute to sperm quality and quantity reductions in some infertile men, including deleterious gene mutations in key genes which are involved in testicular function $[2,3]$.

Mutations in genes involved in folate metabolism may influence spermatogenesis. The methylenetetrahydrofolate reductase gene (MTHFR), which is involved in folate metabolism, has been associated with abnormal spermatogenesis [4]. MTHFR is associated with an important pathway of folate mediated methyl group metabolism. It is also involved in metabolizing thymidine and purine, which are vital for dividing male germ cells to synthesize DNA. The 5,10-Methylenetetrahydrofolate is irreversibly reduced to 5-methyltetrahydrofolate by MTHFR, leading to the synthesis of methyl donor, which is required for methionine synthesis from homocysteine. Similarly, methionine forms S-adenosylmethionine, which is involved in a number of cellular reactions, including DNA, RNA, and histone methylation $[5,6]$.

Homocysteine accumulation and inappropriate methylation lead to DNA damage in spermatozoa which may reduce semen quality, affecting concentration, motility, and morphology of sperm [7, 8]. Therefore, deficiency in folate intake or mutation (s) in the folate pathway enzymes may result in aberrant DNA synthesis and methylation [9].

In adults testis of a mice, the activity of MTHFR is higher than other organs, representing its role in spermatogenesis $[10,11]$. Therefore, alterations in the MTHFR gene could change the process of spermatogenesis and predispose carriers to infertility $[12,13]$.

MTHFR is a gene that regulates the synthesis of methylenetetrahydrofolate enzyme, is a key enzyme in homocysteine and folate metabolism, which acts as a carbon donor for remethylation of homocysteine to methionine. This enzyme reduces 5, 10-methylenetetrahydrofolate to 5,10 -methylenetetrahydrofolate, which is the predominant form of folate in the bloodstream. MTHFR gene is located on chromosome $1 \mathrm{p} 36.3$, composed of 11 exons [14]. A total of 65 polymorphisms have been found in the MTHFR gene. The C677T (rs1801133) polymorphism results in a reduction of enzyme activity by $35 \%$, which adversely affects nucleic acid metabolism [15].

Numerous studies have investigated the relationship between MTHFR gene mutation and male infertility, however, the conclusions are controversial $[1,4-6,9$, 16]. The cause of these conclusions can be attributed to small sample size, definition of infertility, and confounding factors such as ethnicity and race [17]. In the current study, we aim to identify a possible relationship between idiopathic sperm disorders, homocysteine concentration, and the MTHFR C677T mutation in the Iraqi population.

\section{Methods}

All participants provided informed consent before specimens were taken. The medical ethics committee at the University of Kufa/Faculty of Medicine approved the consent protocol for this study. During the period from February 2019 to July 2021, total of 353 infertile male patients and 100 age-matched fertile males were examined for this study. All patients were tested for seminal fluid analysis. Culture media preparation, Giemsa stain, and chromosome cytology have been published elsewhere [18-20].

We selected the patients for the study based on andrology tests, including karyotyping and microdeletions of the $\mathrm{Y}$ chromosome. The study excluded individuals with cryptorchidism, atrophic azoospermia, numerical or structural chromosomal abnormalities, or Y-chromosome microdeletions.

A current case-control study was conducted in the Fertility center of Al-Sadder teaching Hospital and in the laboratories of the Faculty of Medicine/Kufa University in the Province of AL-Najaf /Iraq. The 353 infertile male patients were divided to five groups according to $\mathrm{WHO}$ 2020 criteria of semen parameters (colour, pH, semen volume, liquefaction time by macroscopic analysis while sperm count, sperm motility, and sperm morphology by using microscopic analysis). It is considered normal for men with ' 16 million sperms/milliliter [18]. There were 90 men with lack of sperm as azoospermic, 84 men with sperm count $<16$ million/milliliter were oligospermic, 64 of men with total motility $<42 \%$ of sperm activity were asthenospermic, 65 of men with $<54 \%$ abnormal sperm morphology were teratospermic and 50 of men were oligoasthenospermic, there age range (20-46 years) compared with age matched 100 normal fertile males as control with age range (21-47 years).

Semen examinations were conducted twice a month for each participant after three days of abstinence, after centrifugation for $10 \mathrm{~min}$ at $1006 \times g$, semen samples were analyzed, based on reference values published by the World Health Organization, the mean values of seminal fluid analyses were recorded and used as average results [18].

From all participants a total of five milliliter venous blood samples were collected. one $\mathrm{ml}$ of blood sample was drowning in EDTA tube for DNA extraction, another amount of blood samples were centrifuged for $10 \mathrm{~min}$ at $1006 \times g$, and serum were separated and stored at $-17^{\circ} \mathrm{C}$ until the assayed was performed. Total plasma homocysteine was analyzed according to the manufacturer procedure for determination by using microplate enzyme immunoassay ELISA kit method of Biorad laboratories. The amplification of DNA was done by polymerase chain reaction (PCR) using primers $5^{\prime}$-TGA AGG 
AGA AGG TGT CTG CGG A-3' forward and 5'-AGG ACG GTG CGG TGA GAG TG-3' reverse that resulting of $198 \mathrm{bp}$ PCR product. The reaction was carried out in a $25 \mu \mathrm{l}$ mixture containing (10-100) ng template DNA, 15 pmol of each primer, $20 \mathrm{mM} \mathrm{MgCl} 2,10 \mathrm{mM}$ dNTPs, $5 \mathrm{U} / \mu \mathrm{l}$ Taq polymerase with $10 \times$ Taq Buffer (Promega, USA). The conditions of PCR were as follows: At $94{ }^{\circ} \mathrm{C}$ initial denaturation for $6 \mathrm{~min}$ followed by denaturation of 35 cycles at $94{ }^{\circ} \mathrm{C}$ for $45 \mathrm{~s}$, annealing for $45 \mathrm{~s}$ at $60{ }^{\circ} \mathrm{C}$, extension at $72{ }^{\circ} \mathrm{C}$ for $45 \mathrm{~s}$ and final extension at $72{ }^{\circ} \mathrm{C}$ for $5 \mathrm{~min}$. The $\mathrm{C} 677 \mathrm{~T}$ gene mutation was detected by enzymatic digestion of the initial PCR product with HinfI (Promega.USA) at $37{ }^{\circ} \mathrm{C}$ for $4 \mathrm{~h}$. The resulting of DNA fragments was separated on $3 \%$ agarose gel with ethidiumbromide staining which was then visualized through UV transillumination. Accordingly, Samples who lack the mutation appeared one 198 bp fragment, sample with heterozygous for the mutation revealed both $198 \mathrm{bp}$ and 175 bp fragments, and homozygous sample revealed one $175 \mathrm{bp}$ fragment.

\section{Statistical analysis}

An analysis of statistical data was performed using the SPSS software package (revision 20, Inc., Chicago, USA). Data are expressed as means $\pm \mathrm{SD}$. The Chi-square statistic was used to compare the genotype distributions between patients and controls. In order to estimate the risk of male infertility, odds ratios (ORs) and 95\% confidence intervals $(95 \% \mathrm{CI})$ were calculated. $P<0.05$ values were considered statistically significant.

\section{Results}

A total of 353 infertile men patients and 100 normal fertile men were enrolled in the current study. The patient's group was divided into five subgroups: 90 azoospermia, 84 oligospermia, 64 asthenospermia, 50 oligoasthenospermia, and 65 teratospermia.

The test of chi-square $\left(X^{2}\right)$ was done for analyzed the Hardy Weinberg equilibrium (HWE) among different patients groups and control groups, the results were indicated that an observed and expected frequencies were consistent among the three genotype groups $(P>0.05)$ indicating that the frequency of this sample was representative the Iraqi population.

Three genotypes of CC, CT, and TT were found in the locus 677 of the MTHFR gene in the Iraqi population, the allele distribution along with genotype frequencies of three genotypes are shown in Table 1. Accordingly, 167 subjects (47.3\%) were homozygous of normal allele CC genotype, 116 subjects (32.9\%) were heterozygous of CT genotype, and 70 subjects (21.1\%) homozygous of mutant allele TT genotype. The genotype frequencies of the C677T locus of the MTHFR gene were significantly different when infertile men compared with the control group. $\mathrm{T}$ allele associated with greater risk of infertility in all patients groups for any genetic models; in total infertile subjects (codominant model: $\mathrm{CT}$ vs. $\mathrm{CC}, \mathrm{OR}=2.0$, 95\% C.I $=1.2-3.3, P=0.011$; TT vs. $\mathrm{CC}$, $\mathrm{OR}=4.8$, $95 \%$ C.I $=3.3-8.2, P=0.0003$; dominant model: $\mathrm{CT}+\mathrm{TT}$ vs. $\mathrm{CC}, \mathrm{OR}=2.8,95 \%$ C.I $=1.7-4.5, P=0.0001$ ). Also the same table revealed that oligoasthenospermic patients associated with higher risk in CT heterozygous genotype $(\mathrm{OR}=2.8,95 \%$ C.I $=1.0-4.9, P=0.03)$ and TT homozygous of mutant allele $(\mathrm{OR}=6.3,95 \% \mathrm{C} . \mathrm{I}=1.9-9.2$, $P=0.002$ ).

As shown in Table 2, homocysteine level of each infertile group according to MTHFR gene polymorphism (rs:1801133) genotypes (co-dominant model), was compared with control group and the results showed significant increase in Hcy levels in infertile groups when compared with control group $(P<0.01)$. There were high levels of serum Hcy in homozygous genotype (TT) when compared with heterozygous genotype (CT) and normal allele genotype (CC) in all patient groups. But the highest levels of Serum Hcy was recorded in oligoasthenospermia group $(31.5 \mu \mathrm{mol} / \mathrm{ml})$ followed by the azoospermia group $(28.7 \mu \mathrm{mol} / \mathrm{ml})$, asthenospermia group $(25.9 \mu \mathrm{mol} / \mathrm{ml})$, teratospermia group $(24.2 \mu \mathrm{mol} / \mathrm{ml})$, and oligospermia group $(21.3 \mu \mathrm{mol} / \mathrm{ml})$, whereas the lowest level of Hcy appeared in the control group $(12.1 \mu \mathrm{mol} /$ $\mathrm{ml})$.

As well as, the level of Serum Hcy exhibited the highest level in oligoasthenospermia group of TT mutant genotype $(39.7 \mu \mathrm{mol} / \mathrm{ml})$ followed by CT genotype $(28.5 \mu \mathrm{mol} /$ $\mathrm{ml}$ ) while the lowest level of Hcy was recorded in the CC genotype $(14.6 \mu \mathrm{mol} / \mathrm{ml})$.

\section{Discussion}

Spermatogenesis is a complex development process that involves mitosis, meiosis, and spermiogenesis. Methyl group formation mediated by folate, is one of many pathways regulating this complex process. Besides providing the bases for DNA synthesis in rapidly dividing male germ cells, this pathway is also critical for the removal of homocysteine and several methylation reactions such as methylation of DNA, RNA, histones, and other molecules $[5,21]$. Folate deficiency is associated with various illnesses including male infertility [22]. As a result of changes in folate status, spermatogenesis can be affected by DNA hypomethylation and uracil misincorporation during DNA synthesis, resulting in errors in DNA repair and chromosomal anomalies [23]. There is clear evidence that hyperhomocysteinemia increases the risk of cardiovascular disease [24] and neural tube defects $[25,26]$, but its effects on spermatogenesis remain unclear. The epigenetic architecture of sperm 
Table 1 Genotype frequencies of MTHFR (rs1801133)gene mutation in the studied subjects

\begin{tabular}{|c|c|c|c|c|c|}
\hline Patients group & Genotype & $\begin{array}{l}\text { Patients } \\
n(\%)\end{array}$ & $\begin{array}{l}\text { Control } \\
n(\%)\end{array}$ & $\mathrm{OR}^{\mathrm{a}}(95 \% \mathrm{C} . \mathrm{I})$ & $P$ value \\
\hline \multirow[t]{4}{*}{ Azoospermic $n=90$} & CC & $41(45.5)$ & $70(70)$ & 1 & \\
\hline & $\mathrm{CT}$ & $30(33.3)$ & $25(25)$ & $2.0(1.1-3.9)$ & 0.03 \\
\hline & $\mathrm{TT}$ & 19(21.1) & $5(5)$ & $4.5(2.3-10.7)$ & 0.0005 \\
\hline & $\mathrm{CT}+\mathrm{TT}$ & $49(54.4)$ & $30(30)$ & $2.8(1.5-5)$ & 0.0007 \\
\hline \multirow[t]{4}{*}{ Oligospermic $n=84$} & CC & $42(50)$ & $70(70)$ & 1 & \\
\hline & $\mathrm{CT}$ & $25(29.7)$ & $25(25)$ & $1.7(0.8-3.3)$ & 0.1 \\
\hline & $\mathrm{TT}$ & $17(20.2)$ & $5(5)$ & $3.7(1.9-6.6)$ & 0.002 \\
\hline & $\mathrm{CT}+\mathrm{TT}$ & $42(50)$ & $30(30)$ & $2.3(1.2-4.2)$ & 0.006 \\
\hline \multirow[t]{4}{*}{ Asthenospermic $n=64$} & CC & $31(48.9)$ & $70(70)$ & 1 & \\
\hline & $\mathrm{CT}$ & $24(37.5)$ & $25(25)$ & $2.2(1.0-4.4)$ & 0.03 \\
\hline & $\mathrm{TT}$ & $9(14)$ & $5(5)$ & $4.0(1.2-7.1)$ & 0.01 \\
\hline & $\mathrm{CT}+\mathrm{TT}$ & $33(51.5)$ & $30(30)$ & $2.5(1.3-4.8)$ & 0.006 \\
\hline \multirow[t]{4}{*}{ OligoAsthenospermic $n=50$} & CC & $22(44)$ & $70(70)$ & 1 & \\
\hline & $\mathrm{CT}$ & 18(36) & $25(25)$ & $2.8(1.0-4.9)$ & 0.03 \\
\hline & $\mathrm{TT}$ & $10(20)$ & $5(5)$ & $6.3(1.9-9.2)$ & 0.002 \\
\hline & $C T+T T$ & $28(56)$ & $30(30)$ & $2.9(1.4-6.0)$ & 0.002 \\
\hline \multirow[t]{4}{*}{ Teratospermic $n=65$} & $\mathrm{CC}$ & $31(47.7)$ & $70(70)$ & 1 & \\
\hline & $\mathrm{CT}$ & $19(29)$ & $25(25)$ & $1.7(0.8-3.5)$ & 0.1 \\
\hline & $\mathrm{TT}$ & $15(23.1)$ & $5(5)$ & $5.0(2.2-9.8)$ & 0.0006 \\
\hline & $\mathrm{CT}+\mathrm{TT}$ & 49(75) & $30(30)$ & $3.0(1.6-4.8)$ & 0.0001 \\
\hline \multirow[t]{4}{*}{ Total infertile subjects } & CC & $167(47.3)$ & $70(70)$ & 1 & \\
\hline & $\mathrm{CT}$ & $116(32.9)$ & $25(25)$ & $2.0(1.2-3.3)$ & 0.011 \\
\hline & $\mathrm{TT}$ & $70(21.1)$ & $5(5)$ & $4.8(2.3-8.2)$ & 0.0003 \\
\hline & $\mathrm{CT}+\mathrm{TT}$ & 201(56.9) & $30(30)$ & $2.8(1.7-4.5)$ & 0.0001 \\
\hline
\end{tabular}

$O R^{a}$ adjusted odds ratio, 95\% C.I 95\% confidence interval, $n$ number

Table 2 Comparison of serum homocystein concentrations $(\mu M)$ with patients groups

\begin{tabular}{lcccc}
\hline Patients group & Genotype & & & Hcy concentration \\
\cline { 2 - 4 } & CC & CT & TT & Mean \pm SD \\
\hline Azoospermic & $12.4 \pm 2.7$ & $22.5 \pm 3.2$ & $38.7 \pm 5.1$ & $28.7 \pm 6.1^{*}$ \\
Oligospermic & $10.2 \pm 4.1$ & $19.6 \pm 3.9$ & $35.5 \pm 3.6$ & $21.3 \pm 4.3^{*}$ \\
Asthenospermic & $11.3 \pm 6.1$ & $23.3 \pm 7.1$ & $37.6 \pm 8.2$ & $25.9 \pm 9.4^{*}$ \\
OligoAsthenospermic & $14.6 \pm 3.5$ & $28.5 \pm 7.4$ & $39.7 \pm 6.5$ & $31.5 \pm 7.6^{*}$ \\
Teratospermic & $12.7 \pm 3.8$ & $22.9 \pm 6.3$ & $29.6 \pm 4.6$ & $24.2 \pm 4.3^{*}$ \\
Control group $(n=100)$ & $9.2 \pm 2.3$ & $10.2 \pm 2.6$ & $13.7 \pm 3.2$ & $12.1 \pm 2.6^{*}$ \\
\hline
\end{tabular}

${ }^{*} P<0.01$

DNA has been studied and it has been shown that sperm DNA, histones methylation patterns are vital for normal sperm function, as well as there is significant association between methylation of certain genes and sperm concentration, motility, and morphology [2733]. Numerous studies have suggested that mutations in the MTHFR C677T gene may be associated with decreased sperm counts in the human that lead to male infertility in a number of populations [34-37].

Infertility in men has been studied in different populations to estimate the association between homocysteine levels, MTHFR gene and infertility. In fact, the results were conflicted due to differences in sample size, 
ethnicity, race, geographic variations, genetic variation, and exposure to environmental risk factors [38-40].

Up to our knowledge, there is no data regarding the relationship between the MTHFR C677T polymorphism, homocysteine and semen parameters in Iraqi infertile patients, so this study is designed to assess the relationship of MTHFR gene polymorphism, homocysteine levels, and semen parameters quality in Iraqi population.

The results revealed that MTHFR C677T gene mutation is a risk factor for male infertility in our population, also, it appeared high homocysteine levels in azoospermic, oligospermic, asthenospermic, teratospermic, and oligoasthenospermic patients groups. Highest level was in oligoasthenospermic group. TT mutant genotype was more than CT genotype while the lowest level of homocysteine recorded in CC genotype.

Our results were consistent with the Egyptian study which one [41] out of four studies in Africa showed a high association of $677 \mathrm{~T}$ with men's infertility [41-44]. A two Iranian studies were found that carriers of the $677 \mathrm{~T}$ allele (CT and TT genotypes) at a higher risk of infertility than individuals with other genotypes [45, 46], In Chinese men with azoospermia and severe oligozoospermia, an SNP in the MTHFR gene appeared to be associated with infertility [47], an Italian study of Lombardo et al. [48] who recorded that a function of C677T mutation in MTHFR leads to hyperhomocysteinemia, is associated with erectile dysfunction mainly in homozygous 677 TT patients. Also in France Montjean et al. [49] and Ménézo et al. [50] was recorded the MTHFR 677TT genotype is combined with significantly increased plasma homocysteine levels, in Netherlands Boxmeer et al. [51] was recorded increased sperm damage by increased homocysteine and decreased folate in seminal plasma. A number of Asian studies [52-55] expressed this association, Mutant genotypes are significantly associated with fertility by Gupta et al. [56] and Kumari et al. [57] studies in India, another study in Italy that conducted by Paracchini et al. [58] was found the risk of infertility increased with TT genotype in the C677T locus of MTHFR gene.

In contrast, the MTHFR $677 \mathrm{~T}$ mutation was found to be protective for Moroccan infertile men [59]. Other studies in the Indian population $[60,61]$ were deserved no significant differences of C677T variants between fertile and infertile males. Celia et al. [62] found no evidence for an association between C677T polymorphism in enzymes involved in folate metabolism and reduced sperm counts in the French population.

\section{Conclusion}

By relating the MTHFR C677T gene mutation with a higher homocysteine level, the results showed that Iraqi males with this mutation are more likely to suffer from infertility. Additional data are needed to confirm our conclusion and provide an important relationship between genes and the environment that affects male infertility risk.

\section{Abbreviations}

MTHFR: Methyltetrahydrofolate reductase; Hcy: Homocysteine; ELISA: Enzymelinked immunosorbent assay; PCR-RFLP: Polymerase chain reaction-restriction fragment length polymorphism; C: Cytosine; T: Thymine; OR: Odds ratio; C.I: Confidence interval; P: Probability; $X^{2}$ : Chi-square; HWE: Hardy Weinberg equilibrium; SPSS: Statistical package for the social sciences.

\section{Acknowledgements}

The authors want to thank all individuals who participate in this study, gratitude should also be expressed to the staff of the Fertility Center for their supporting during sample collection, mainly Fertility Center in Al-Sadder teaching hospital in Najaf/Iraq.

\section{Authors' contributions}

A substantial and intellectual contribution has been made by each author and the work has been approved for publication by all of them. AM and SM contributed to the conceptualization. AM, SM and SA were involved in formal analysis and literature search. Sample collection, data acquisition and methodology, biochemical and genetic analyses were done by AM and SM. Statistical analysis was calculated by AM. AM, SM and SA contributed to the manuscript editing and review. AM and SM contributed to the manuscript revision. All authors read and approved the final manuscript.

\section{Funding}

No funding.

Availability of data and materials

The datasets used and/or analyzed during the current study are available from the corresponding author on request.

\section{Declarations}

\section{Ethics approval and consent to participate}

The study was conducted after gaining approval from the medical ethics committee (Kufa Faculty of Medicine/University of Kufa, Najaf) vide Reference \#: MEC-09 dated 19.2.2019. Written informed consent was taken from the study participants.

\section{Consent for publication \\ Not applicable.}

\section{Competing interests}

The authors declare that they have no competing interests.

\section{Author details}

${ }^{1}$ Department of Clinical Chemistry, College of Medicine, University of Kufa, Najaf, Iraq. ${ }^{2}$ Department of Anatomy and Histology, College of Medicine, University of Kufa, Najaf, Iraq. ${ }^{3}$ Department of Anatomy and Histology, College of Medicine, University of AL-Ameed, Karbala, Iraq.

Received: 9 October 2021 Accepted: 28 February 2022

Published online: 05 March 2022

References

1. Katherine L, O'Flynn O'Brien KL, Varghese AC, Agarwal A (2010) The genetic causes of male factor infertility: a review. Fertil Steril 93:1-12

2. Agarwal A, Roychoudhury S, Sharma R, Gupta S, Majzoub A, Sabanegh E (2017) Diagnostic application of oxidation-reduction potential assay for measurement of oxidative stress: clinical utility in male factor infertility. Reprod Biomed Online 34(1):48-57 
3. Bashamboo A, Ferraz-de-Souza B, Lourenço D, Lin L, Sebire NJ, Montjean D et al (2010) Human male infertility associated with mutations in NR5A1 encoding steroidogenic factor1. Am J Hum Genet 87:505-512

4. Shen O, Liu R, Wu W, Yu L, Wang X (2012) Association of the methylenetetrahydrofolate reductase gene A1298C polymorphism with male infertility: a meta-analysis. Ann Hum Genet 76:25-32

5. Singh K, Jaiswal D (2013) One-carbon metabolism, spermatogenesis, and male infertility. Reprod Sci 20:622-630

6. Xudong Z, Zhiguo L, Maochen Z, Ruihong G, Yajun X, Baoming W (2016) Association of the methylenetetrahydrofolate reductase gene C677T polymorphism with the risk of male infertility: a meta-analysis. Ren Fail 38(2):185-193

7. Duthie SJ, Narayanan S, Blum S, Pirie L, Brand GM (2013) Folate deficiency in vitro induces uracil misincorporation and DNA hypomethylation and inhibits DNA excision repair in immortalized normal human colon epithelial cells. Nutr Cancer 37:37-41

8. Lewis SEM, Aitken RJ (2005) DNA damage to spermatozoa has impacts on fertilization and pregnancy. Cell Tissue Res 322:33-41

9. Zhou-Cun A, Yuan Y, Si-Zhong Z, Na L, Wei Z (2007) Single nucleotide polymorphism C677T in the methylenetetrahydrofolate reductase gene might be a genetic risk factor for infertility for Chinese men with azoospermia or severe oligozoospermia. Asian J Androl 9(1):57-62

10. Dhillon VS, Shahid M, Husain SA (2007) Associations of MTHFR DNMT3b 4977bp deletion in mtDNA and GSTM1 deletion, and aberrant CpG island hypermethylation of GSTM1 in non-obstructive Infertility in Indian men. Mol Hum Reprod 13:213-222

11. Chen Z, Karaplis AC, Ackerman SL, Pogribny IP, Melnyk S et al (2001) Mice deficient in methylenetethrahydrofolate reductase exhibit hyperhomocysteinemia and decreased methylation capacity, with neuropathology and aortic lipid deposition. Hum Mol Genet 10:433-443

12. Khazamipour N, Noruzinia M, Fatehmanesh P, Keyhanee M, Pujol P (2009) MTHFR promoter hypermethylation in testicular biopsies of patients with nonobstructive azoospermia: the role of epigenetics in male infertility. Hum Reprod 24:2361-2364

13. Singh K, Singh SK, Raman R (2010) MTHFR A1298C polymorphism and idiopathic male infertility. J Postgrad Med 56:267-269

14. Rabab M, Mona M, Hayam F (2014) MTHFR A1298C and C677T gene polymorphisms and susceptibility to chronic myeloid leukemia in Egypt. Int J Clin Exp Pathol 7(5):2571-2578

15. AL-Dewachi SO, Kashmoola MA (2020) Methyltetrahydrofolate reductase (MTHFR) Mutations in Healthy Individuals in Ninavah Province, Iraq. Ann Trop Med Public Health 23:13

16. Hong HH et al (2017) Associations of C677T polymorphism in methylenetetrahydrofolate reductase (MTHFR) gene with male infertility risk: a meta-analysis. Eur J Obstet Gynecol Reprod Biol 212:101-109

17. Fereshteh A, Farkhondeh P, Nahal E, Zahra Z, Faezeh A (2020) Association of the MTHFR 677 C $>$ T and 1298A $>$ C polymorphisms and male infertility risk: a meta-analysis. Reprod Biol Endocrinol 18:93

18. World Health Organization (2021) Laboratory manual for the examination and processing of human semen 2021, 6th edn. Cambridge University Press, Cambridge

19. Guney Al et al (2012) Detection of Y chromosome microdeletions and mitochondrial DNA mutations in male infertility patients. Genet Mol Res 11:1039-1048

20. Hopps CV et al (2003) Detection of sperm in men with $Y$ chromosome microdeletions of the AZFa, AZFb and AZFc regions. Hum Reprod 18:1660-1665

21. Maclean JA, Wilkinson MF (2005) Gene regulation in spermatogenesis. Curr Top Dev Biol 71:131-197

22. Ni W, Li H, Wu A, Zhang P, Yang H, Yang X, Huang X, Jiang L (2015) Lack of association between genetic polymorphisms in three folate-related enzyme genes and male infertility in the Chinese population. J Assist Reprod Genet 32:369-374

23. Lee HC, Jeong YM, Lee SH, Cha KY, Song SH, Kim NK, Lee HC, Jeong YM, Lee SH, Cha KY, Song SH, Kim NK (2006) Association study of four polymorphisms in three folaterelated enzyme genes with non-obstructive male infertility. Hum Reprod 21:3162-3170

24. Ganguly P, Alam SF (2015) Role of homocysteine in the development of cardiovascular disease. Nutr J 14:6

25. Apolline I, Jean-François B, Henk JB (2013) Neural tube defects, folic acid and methylation. Int J Environ Res Public Health 10:4352-4389
26. Yu Y, Jia C, Shi Q, Zhu Y, Liu Y (2019) Hyperhomocysteinemia in men with a reproductive history of fetal neural tube defects: three case reports and literature review. Medicine 98:2

27. Marques CJ, Carvalho F, Sousa M, Barros A (2004) Genomic imprinting in disruptive spermatogenesis. Lancet 363:1700-1702

28. Molaro A, Hodges E, Fang F, Song Q, McCombie WR, Hannon GJ et al (2011) Sperm methylation profiles reveal features of epigenetic inheritance and evolution in primates. Cell 146:1029-1041

29. Aston Kl, Punj V, Liu L, Carrell DT (2012) Genome-wide sperm deoxyribonucleic acid methylation is altered in some men with abnormal chromatin packaging or poor in vitro fertilization embryogenesis. Fertil Steril 97:285-292

30. Carrell DT (2012) Epigenetics of the male gamete. Fertil Steril 97:267-274

31. Navarro-Costa P, Nogueira P, Carvalho M, Leal F, Cordeiro I, Calhaz-Jorge C et al (2010) Incorrect DNA methylation of the DAZL promoter CpG island associates with defective human sperm. Hum Reprod 25:2647-2654

32. Pacheco SE, Houseman EA, Christensen BC, Marsit CJ, Kelsey KT, Sigman M et al (2011) Integrative DNA methylation and gene expression analyses identify DNA packaging and epigenetic regulatory genes associated with low motility sperm. PLOS ONE 6:e20280

33. Hammoud SS, Purwar J, Pflueger C, Cairns BR, Carrell DT (2010) Alterations in sperm DNA methylation patterns at imprinted loci in two classes of infertility. Fertil Steril 94:1728-1733

34. Bezold G, Lange M, Peter RU (2001) Homozygous methylenetetrahydrofolate reductase C677T mutation and male infertility. N Engl J Med 344(1172-3):17

35. Park JH, Lee HC, Jeong YM, Chung TG, Kim HJ et al (2005) MTHFR C677T polymorphism associates with unexplained infertile male factors. J Assist Reprod Genet 22:361-368

36. Singh K, Singh SK, Sah R, Singh I, Raman R (2005) Mutation C677T in the methylenetetrahydrofolate reductase gene is associated with male infertility in an Indian population. Int J Androl 28:115-119

37. Lee HC, Jeong YM, Lee SH, Cha KY, Song SH, Kim NK, Lee KW, Lee S (2006) Association study of four polymorphisms in three folate-related enzyme genes with non-obstructive male infertility. Hum Reprod 21:3162-3170

38. Chong X, Ping P, Yi M, Zhengmu W, Xiangfeng C (2019) Correlation between methylenetetrahydrofolate reductase gene polymorphism and oligoasthenospermia and the effects of folic acid supplementation on semen quality. Transl Androl Urol 8(6):678-685

39. Aitken RJ, Flanagan HM, Connaughton $\mathrm{H}$ et al (2016) Involvement of homocysteine, homocysteine thiolactone, and paraoxonase type 1 (PON-1) in the etiology of defective human sperm function. Andrology 4:345-360

40. Kralikova M, Crha I, Huser M et al (2017) The intracellular concentration of homocysteine and related thiols is negatively correlated to sperm quality after highly effective method of sperm lysis. Andrologia 49(7):e12702

41. Zalata AA, Badawy A, Mokhtar N, Serria MS, Abdeen HM, Alghobary M et al (2011) Mutations in the methy-lenetetrahydrofolate reductase gene and methionine metabolism in male infertility. Bull Egypt Soc Physiol Sci 31(2):221-240

42. Hussein TM, Elneely DI (2014) Y-chromosome microdeletions and the MTHFR C677T polymorphism in Egyptian men with nonobstructive azoospermia. Hum Androl 4(3):66-70

43. Chellat D, Rezgoune ML, Hamane D, Semmame O, Benlatréche C, Abadi $\mathrm{N}$ et al (2012) Influence of methylenetetrahydrofolate reductase C677T gene polymorphisms in Algerian infertile men with azoospermia or severe oligozoospermia. Genet Test Mol Bio-mark 16(8):874-878

44. Eloualid A, Abidi O, Charif M, El Houate B, Benrahma H, Louanjli $N$ et al (2012) Association of the MTHFR A1298C variant with unexplained severe male infertility. PLoS ONE 7(3):e34111

45. Mohammad K, Abasalt H (2016) Association of C677T transition of the human methylenetetrahydrofolate reductase (MTHFR) gene with male infertility. Reprod Fertil Dev 28(6):785-794

46. Tara SS, Ghaemimanesh F, Zarei S, Reihani-Sabet F, Pahlevanzadeh Z, Modarresi MH, Jeddi-Tehrani M (2015) Methylenetetrahydrofolate reductase C677T and A1298C polymorphisms in male partners of recurrent miscarriage couples. Reprod Infertil 16(4):193-198

47. Zhou-Cun A, Yuan Y, Si-Zhong Z, Na L, Wei Z (2007) Single nucleotide polymorphism C677T in the methylenete-trahydrofolate reductase gene might be a genetic risk factor for infertility for Chinese men with azoospermia or severe oligospermia. Asian J Androl 9:57-62 
48. Lombardo F, Tsamatropoulos P, Piroli E et al (2010) Treatment of erectile dysfunction due to C677T mutation of the MTHFR gene with vitamin B6 and folic acid in patients non responders to PDE5i. J Sex Med $7(1): 216-223$

49. Montjean D, Benkhalifa M, Dessolle L, Cohen-Bacrie P, Belloc S, Jean-Pierre Siffroi J et al (2011) Polymorphisms in MTHFR and MTRR genes associated with blood plasma homocysteine concentration and sperm counts. Fertil Steril 95:2

50. Ménézo Y, Patrizio P, Alvarez S, Amar E, Brack M, Brami C et al (2021) MTHFR (methylenetetrahydrofolate reductase: EC 1.5.1.20) SNPs (singlenucleotide polymorphisms) and homocysteine in patients referred for investigation of fertility. J Assist Reprod Genet 38(9):2383-2389

51. Boxmeer JC, Smit M, Utomo E, Romijn JC, Eijkemans MJ, Lindemans J et al (2009) Low folate in seminal plasma is associated with increased sperm DNA damage. Fertil Steril 92:548-556

52. Pei J (2013) Association between MTHFR C677T polymorphism and male infertility in Han population of He Nan China. China Hlth Care Nutr 2(7):629-630

53. Naqvi H, Hussain SR, Ahmad MK, Mahdi F, Jaiswar SP, Shankhwar SN et al (2014) Role of $677 C \rightarrow$ T polymorphism a single substitution in methylenetetrahydro-folate reductase (MTHFR) gene in North Indian infertile men. Mol Biol Rep 41(2):573-579

54. Karimian M, Colagar AH (2016) Association of C677T transition of the human methylenetetrahydrofolate reductase (MTHFR) gene with male infertility. Reprod Fertil Dev 28(6):785-794

55. Nikzad H, Karimian M, Sareban K, Khoshsokhan M, Colagar AH (2015) MTHFR-Ala222Val and male infertility: a study in Iranian men, an updated meta-analysis and an in silico-analysis. Reprod BioMed Online 31(5):668-680

56. Gupta N, Gupta S, Dama M, David A, Khanna G, Khanna A et al (2011) Association of $677 \mathrm{C}>$ T substitution in the MTHFR gene with male infertility - a study on an Indian population and a meta-analysis. PLoS ONE 6(7):e22277

57. Kumari R (2013) Genetic interaction between methylene- tetrahydrofolate reductase C677T gene polymorphisms and stem cell associated "risk factor" in male infertility. Sch J App Med Sci 1(5):552-556

58. Paracchini V, Garte S, Taioli E (2006) MTHFR C677T polymorphism, GSTM1 deletion and male infertility: a possible suggestion of a gene-gene interaction? Biomarkers 11:53-60

59. Sun HT, Zhang JY, Lu YJ (2007) Associated of the meth-ylenetetrahydrofolate reductase gene C677T polymorphism with male infertility. Reprod Contracept 27(7):443-446

60. Dhillon VS, Shahid M, Husain SA (2007) Associations of MTHFR DNMT3b 4977bp deletion in mtDNA and GSTM1 deletion, and aberrant CpG island hypermethylation of GSTM1 in nonobstructive Infertility in Indian men. Mol Hum Reprod 13(4):213-222

61. Vani GT, Mukesh N, Devi PR, Rani PU, Reddy PP (2012) Methylenetetrahydrofolate reductase C677T polymorphism is not associated with male infertility in a South Indian population. Andrologia 44(1):252-259

62. Celia R, Sandra CB, Clementine C, Luis B, Isabelle AS, Jerome P et al (2009) Lack of association between genetic polymorphisms in enzymes associated with folate metabolism and unexplained reduced sperm counts. PLOS ONE 4(8):e6540

\section{Publisher's Note}

Springer Nature remains neutral with regard to jurisdictional claims in published maps and institutional affiliations. 